\title{
Pediatric Mania: The Controversy between Euphoria and Irritability
}

\section{Citation}

Serra, Giulia, Mai Uchida, Claudia Battaglia, Maria Pia Casini, Lavinia

De Chiara, Joseph Biederman, Stefano Vicari, and Janet Wozniak. 2017.

"Pediatric Mania: The Controversy between Euphoria and Irritability." Current

Neuropharmacology 15 (3): 386-393. doi:10.2174/1570159X14666160607100403. http://

dx.doi.org/10.2174/1570159X14666160607100403.

\section{Published Version}

doi:10.2174/1570159X14666160607100403

\section{Permanent link}

http://nrs.harvard.edu/urn-3:HUL.InstRepos:34492389

\section{Terms of Use}

This article was downloaded from Harvard University's DASH repository, and is made available under the terms and conditions applicable to Other Posted Material, as set forth at http:// nrs.harvard.edu/urn-3:HUL.InstRepos:dash.current.terms-of-use\#LAA

\section{Share Your Story}

The Harvard community has made this article openly available.

Please share how this access benefits you. Submit a story.

Accessibility 
RESEARCH ARTICLE

\title{
Pediatric Mania: The Controversy between Euphoria and Irritability
}

\author{
Giulia Serra $^{\mathrm{a}-\mathrm{c}, \mathrm{e},}$, Mai Uchida ${ }^{\mathrm{d}, \mathrm{e}}$, Claudia Battaglia ${ }^{\mathrm{a}}$, Maria Pia Casini ${ }^{\mathrm{a}}$, Lavinia De Chiara ${ }^{\mathrm{b}, \mathrm{c}}$, \\ Joseph Biederman ${ }^{\mathrm{d}, \mathrm{e}}$, Stefano Vicari ${ }^{\mathrm{a}}$ and Janet Wozniak ${ }^{\mathrm{d}, \mathrm{e}}$
}

\begin{abstract}
${ }^{a}$ Child Psychiatry Unit, Department of Neuroscience Bambino Gesù Children's Hospital, IRCCS Rome, Italy; ${ }^{b}$ NESMOS Department (Neuroscience, Mental Health, and Sensory Organs), Sapienza University, School of Medicine and Psychology, Sant'Andrea Hospital, Rome, Italy; ${ }^{c}$ Lucio Bini Mood Disorder Center, Rome, Italy; ${ }^{d}$ Massachusetts General Hospital, Department of Pediatric Psychopharmacology, Boston, MA, United States; ${ }^{e}$ Harvard Medical School, Department of Psychiatry, Boston, MA, United States
\end{abstract}

\begin{abstract}
Pediatric Bipolar Disorder (BD) is a highly morbid pediatric psychiatric disease, consistently associated with family psychiatric history of mood disorders and associated with high levels of morbidity and disability and with a great risk of suicide. While there is a general consensus on the symptomatology of depression in childhood, the phenomenology of pediatric mania is still highly debated and the course and long-term outcome of pediatric BD still need to be clarified. We reviewed the available studies on the phenomenology of pediatric mania with the aim of summarizing the prevalence, demographics, clinical correlates and course of these two types of pediatric mania. Eighteen studies reported the number of subjects presenting with either irritable or elated mood during mania. Irritability has been reported to be the most frequent clinical feature of pediatric mania reaching a sensitivity of $95-100 \%$ in several samples. Only half the studies reviewed reported on number of episodes or cycling patterns and the described course was mostly chronic and ultra-rapid whereas the classical episodic presentation was less common.

Few long-term outcome studies have reported a diagnostic stability of mania from childhood to young adult age. Future research should focus on the heterogeneity of irritability aiming at differentiating distinct subtypes of pediatric psychiatric disorders with distinct phenomenology, course, outcome and biomarkers. Longitudinal studies of samples attending to mood presentation, irritable versus elated, and course, chronic versus episodic, may help clarify whether these are meaningful distinctions in the course, treatment and outcome of pediatric onset bipolar disorder.
\end{abstract}

A R T I C L E H I S T O R Y

Received: November 20, 2015

Revised: May 10, 2016

Accepted: May 24, 2016

DOI:

$10.2174 / 1570159 \times 14666160607100$

403

Keywords: Adolescence, bipolar disorder, cardinal symptoms, childhood, irritability, mania.

\section{INTRODUCTION}

Bipolar Disorder (BD) during childhood (age $\leq 12$ years) and adolescence (age 13-18 years) was first described in antiquity by Aretaeus of Cappadocia (in 150 C.E), later reported by Esquirol in the early 1800s and then by Kraepelin and his contemporaries [1]. In recent times, converging evidence supports the notion that pediatric bipolar disorder is a highly morbid pediatric psychiatric disorder and that its prevalence is around 1.8\% [CI 1.1-3.0] with similar rates in European and American countries [2].

Pediatric BD (PBD) is consistently and significantly associated with family psychiatric history of mood disorders [3], with increased risk in subjects who have a loaded (more than three members affected) and a multigenerational

*Address correspondence to this author at the Child Neuropsychiatry Unit, Dept. of Neuroscience, I.R.C.C.S. Children Hospital Bambino Gesù, Rome, Italy; Tel: +39-334-3654252; E-mail: giuliaserra@gmail.com family history of mood disorder or a family history of mania $[4,5]$.

The diagnosis of PBD is complicated by a highly debated clinical picture and very high rate of comorbidity with other juvenile psychiatric disorders (attention deficit and hyperactivity, oppositional defiant and conduct disorders) with frequently overlapping symptomatology [6]. The clinical phenomenology and course of illness of PBD often differs from the classical episodic presentation of manic-depressive illness with clear cycling and periods of inter-morbid high functioning and instead often resembles the more severe and treatment resistant adult forms of $\mathrm{BD}$ with rapid-cycling course and mixed features with irritability, dysphoria and high risk of suicidal behaviors $[1,6,7]$.

Age of onset can be identified during the preschool years with an age-dependent developmentally distinct symptomatology. Initial symptoms appearing during the preschool years often include irritability, moodiness, sleep 
Table 1. Phenomenology and course of pediatric mania.

\begin{tabular}{|c|c|c|c|c|c|c|c|}
\hline $\begin{array}{l}\text { Author and } \\
\text { Year }\end{array}$ & $\begin{array}{l}\text { Study Design; } \\
\text { Type of } \\
\text { Sample }\end{array}$ & $\mathbf{N}$ & $\begin{array}{l}\text { Age } \\
\text { (Range and } \\
\text { Mean (SD)) }\end{array}$ & Diagnosis & $\begin{array}{l}\text { Dx criteria } \\
\text { and Mania } \\
\text { Symptoms } \\
\text { Rating Scale }\end{array}$ & $\begin{array}{l}\text { Manic Symptoms in BD Samples: } \\
\text { Number of Subjects (\%) or } \\
\text { Symptoms Rating (Mean (SD)) }\end{array}$ & $\begin{array}{c}\text { Course Type } \\
\text { (n, \%of Sample) }\end{array}$ \\
\hline $\begin{array}{l}\text { Axelson, } 2006 \\
\text { AGP [36] }\end{array}$ & $\begin{array}{l}\text { Cross-sectional; } \\
\text { clinical and } \\
\text { community } \\
\text { sample }\end{array}$ & 438 & $\begin{array}{l}7-18 \text { years } \\
12.7(3.2) \\
\text { years }\end{array}$ & $\begin{array}{c}\text { BDI } 220 \\
\text { BD-NOS } \\
116\end{array}$ & $\begin{array}{l}\text { DSM-IV; } \\
\text { COBY criteria } \\
\text { for BD-NOS }\end{array}$ & $\begin{array}{l}\text { Irritability: BDI } 84.5 \text {; BD-NOS } 80.2 \\
\text { Elation: BDI 91.8; BD-NOS } 81.9 \\
\text { Grandiosity: BDI 75.5; BD-NOS } 62.1\end{array}$ & N/A \\
\hline $\begin{array}{c}\text { Biederman, } 2004 \\
\text { JAD [25] }\end{array}$ & $\begin{array}{l}\text { Longitudinal, } \\
\text { controlled; } \\
\text { clinical sample }\end{array}$ & 786 & $\begin{array}{l}\leq 12 \text { years } \\
8.5(2.3)\end{array}$ & BD 172 & $\begin{array}{l}\text { DSM-III R } \\
\text { DSM-IV }\end{array}$ & $\begin{array}{c}\text { Irritability: } 92 \%^{\mathrm{a}} \\
\text { Euphoria: } 33 \% \\
\text { Euphoria + Irritability: } 25 \% \\
\text { Euphoria without Irritability: } 8 \%\end{array}$ & $\begin{array}{l}\text { Chronic: } 80 \%{ }^{\mathrm{b}} \\
\text { Episodic: } 20 \%{ }^{\mathrm{c}}\end{array}$ \\
\hline $\begin{array}{l}\text { Birmaher, } 2009 \\
\quad \text { Bipolar } \\
\text { Disorders [38] }\end{array}$ & $\begin{array}{l}\text { Cross-sectional; } \\
\text { clinical sample } \\
\text { (out- and } \\
\text { inpatients, } \\
\text { advertisement) }\end{array}$ & 264 & $\begin{array}{c}\text { A. } \leq 12 \text { years } \\
9.4(1.5) \\
\text { B. }>12 \text { years; } \\
14.5(1.7) \\
\text { C. }>12 \text { years; } \\
16(1.3)^{\text {d }}\end{array}$ & $\begin{array}{l}\text { A. BD } 73 \\
\text { B. BD } 101 \\
\text { C. BD } 90\end{array}$ & $\begin{array}{c}\text { DSM-IV; } \\
\text { COBY criteria } \\
\text { for BD-NOS; } \\
\text { K-MRS 13- } \\
\text { item scale } \\
\text { score }\end{array}$ & $\begin{array}{c}\text { Elation: A 3.9(1.2); B 4.3(1.0); C 4.4(1.0) } \\
\text { Irritability: A 4.1(1.5); B 4.3(1.4); C 3.7(1.4) } \\
\text { Grandiosity :A 3.0(1.4); B 3.5(1.5); C 3.6(1.3) }\end{array}$ & N/A \\
\hline $\begin{array}{l}\text { Demeter, } 2013 \\
\text { JAD [32] }\end{array}$ & $\begin{array}{l}\text { Cross-sectional, } \\
\text { outpatient } \\
\text { clinical sample }\end{array}$ & 535 & $\begin{array}{l}4-17 \text { years } \\
10.5(3.5)\end{array}$ & $\begin{array}{c}\text { BDI } 290 \\
\text { BDII } 17 \\
\text { BD NOS } \\
155 \\
\text { CYCLO } 73\end{array}$ & $\begin{array}{l}\text { DSM-IV } \\
\text { K-MRS 13- } \\
\text { item scale } \\
\text { score }\end{array}$ & $\begin{array}{c}\text { Irritability: BDI 4.7(1.7), BDII or NOS 3.3(1.6) } \\
\text { Elation: BDI } 2.5(1.0), \text { BDII or NOS } 2.0(0.9) \\
\text { Grandiosity: BDI } 2.6(1.3) \\
\text { BDII or NOS } 2.1(1.1)\end{array}$ & \\
\hline $\begin{array}{l}\text { Faedda, } 2004 \\
\text { JAD [24] }\end{array}$ & $\begin{array}{l}\text { Retrospective; } \\
\text { outpatient } \\
\text { clinical sample }\end{array}$ & 82 & $\begin{array}{l}3-17 \text { years } \\
10.6(3.6)\end{array}$ & $\begin{array}{l}\text { BDI } 43 \\
\text { BDII } 33 \\
\text { CYCLO } 6\end{array}$ & DSM-IV & $\begin{array}{c}\text { Irritability: 97.6; Angry: } 92.7 \\
\text { Euphoric, grandiose: } 59.8\end{array}$ & $\begin{array}{l}\text { UU-RC: } 65.9^{\mathrm{e}} \\
\text { Seasonal: } 14.6 \\
\text { U-RC } 12.2 \\
\text { RC: } 7.4\end{array}$ \\
\hline $\begin{array}{l}\text { Geller, } 2000 \\
\text { JCAP [9] }\end{array}$ & $\begin{array}{l}\text { Longitudinal; } \\
\text { clinical } \\
\text { outpatients } \\
\text { sample }\end{array}$ & 93 & $\begin{array}{l}7-16 \text { years } \\
10.9(2.6)\end{array}$ & $\begin{array}{l}\text { Pre-pubertal } \\
\text { BD } 53 \\
\text { Pubertal BD } \\
\quad 40\end{array}$ & DSM-IV ${ }^{f}$ & $\begin{array}{l}\text { Irritable mood: all 97.9; Pre-pub 96.2; Pub } 100^{\mathrm{g}} \\
\text { Elated mood: all 89.3; Pre-pub 88.7; Pub } 90 \\
\text { Grandiosity: all 86.0; Pre-pub 84.9; Pub } 87.5\end{array}$ & $\begin{array}{l}\text { UU-RC: all 77.4; Pre- } \\
\text { pub } 81.1 ; \text { Pub } 72.5^{\text {e }} \\
\text { U-RC: all 9.7; Pre-pub } \\
\text { 3.8; Pub } 17.5\end{array}$ \\
\hline $\begin{array}{l}\text { Geller, } 2002 \\
\text { JCAP [10] }\end{array}$ & $\begin{array}{l}\text { Longitudinal; } \\
\text { clinical } \\
\text { outpatients } \\
\text { sample and } \\
\text { random } \\
\text { controls }\end{array}$ & 238 & $\begin{array}{c}7-16 \text { years } \\
\text { BD } 10.9 \\
(2.6) \\
\text { ADHD } \\
9.7(2.0) \\
\text { HC } 11.0 \\
(2.6)\end{array}$ & $\begin{array}{l}\text { BD } 93 \\
\text { ADHD } 81 \\
\text { HC } 94\end{array}$ & DSM-IV & $\begin{array}{l}\text { Irritable mood: BD 97.9; ADHD 71.6; HC } 3.2^{\mathrm{h}} \\
\text { Elated mood: BD 89.3; ADHD 13.6; HC } 0.0^{\mathrm{g}} \\
\text { Grandiosity: BD 86.0; ADHD 4.9; HC } 1.1^{1}\end{array}$ & $\begin{array}{l}\text { UU-RC: BD } 77.4 \\
\text { U-RC: BD } 9.7\end{array}$ \\
\hline $\begin{array}{l}\text { Hunt, } 2009 \\
\text { JCAP [31] }\end{array}$ & $\begin{array}{l}\text { Retrospective; } \\
\text { clinical sample } \\
\text { (out- and } \\
\text { inpatients, } \\
\text { advertisement) }\end{array}$ & 361 & $\begin{array}{l}7-16 \text { years } \\
12.5(3.3)\end{array}$ & $\begin{array}{l}\text { BDI } 226 \\
\text { BDII } 20 \\
\text { BD NOS } \\
115\end{array}$ & $\begin{array}{l}\text { DSM-IV; } \\
\text { COBY criteria } \\
\text { for BD-NOS }\end{array}$ & $\begin{array}{l}\text { Irritability only: } 10.0 \\
\text { Elation only: } 15.0 \\
\text { Irritability + Elation: } 75.1\end{array}$ & \\
\hline $\begin{array}{l}\text { Hunt, } 2013 \\
\text { JCP [35] }\end{array}$ & $\begin{array}{l}\text { Longitudinal } \\
\text { (4 years follow- } \\
\text { up); clinical } \\
\text { sample } \\
\text { (out- and } \\
\text { inpatients, } \\
\text { advertisement) }\end{array}$ & 309 & $\begin{array}{l}7-16 \text { years } \\
10.5(2.8)\end{array}$ & BD 309 & $\begin{array}{l}\text { DSM-IV; } \\
\text { COBY criteria } \\
\text { for BD-NOS }\end{array}$ & $\begin{array}{c}\text { Irritability only: } 9.7 \\
\text { Elation only: } 13.6 \\
\text { Irritability + Elation: } 76.7\end{array}$ & $\begin{array}{l}\text { - All groups showed a } \\
\text { significant decrease in } \\
\text { severity of irritability } \\
\text { and elation score } \\
\text { during follow-up. } \\
\text { - Irritable only youth } \\
\text { were at similar risk for } \\
\text { mania but at greater } \\
\text { risk for depression } \\
\text { compared with elated- } \\
\text { only youth and youth } \\
\text { who had both } \\
\text { irritability and elation } \\
\text { symptoms. }\end{array}$ \\
\hline
\end{tabular}


(Table 1) contd....

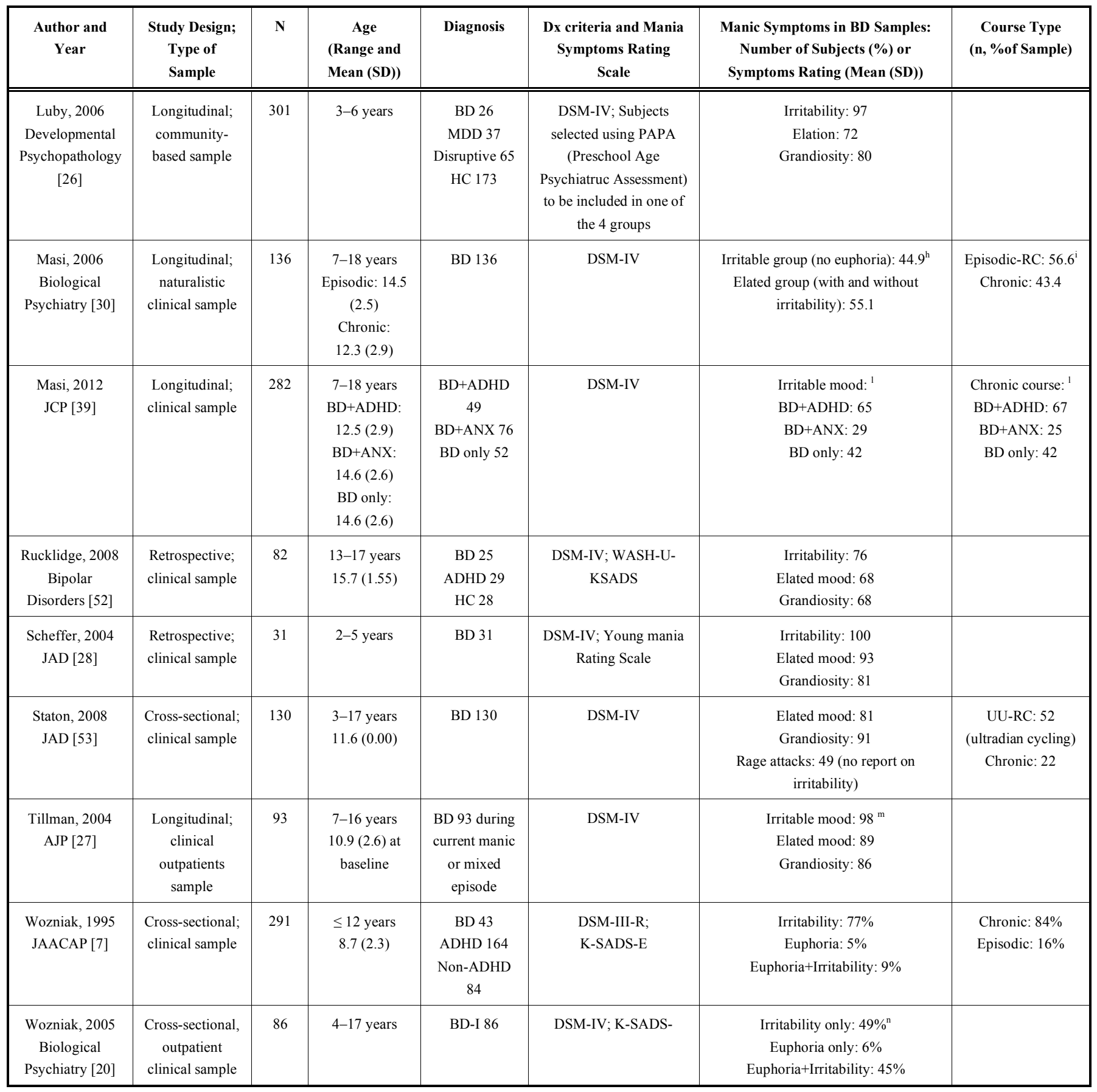

Notes: a. $\mathrm{N}=36 \mathrm{BD}$ subjects had available symptoms data; $\mathbf{b}$. Chronic course included rapid cycling, multiple episodes lasting $\geq 12$ months, or a single episode lasting $\geq 12$ months; c. Episodic course refers to children with episodes lasting $<12$ months or a single, brief episode; d. Group A children, group B adolescents with childhood-onset BD, group C adolescents with adolescent onset BD. d. Irritability score significantly decreased linearly with age ( $<<0.01$ ) and was higher among BDI $v s$. BDII or NOS ( $<0.05$ ); e. course of illness: UU-RC (ultra-ultra-rapid cycling, $>365$ phases/year), URC (ultra-rapid cycling, 5-365 phases/year), RC (rapid cycling $\geq 4$ phases/year); seasonal (exacerbations or recurrences with seasonal pattern for $\geq 2$ consecutive years); f. Subjects needed to have current DSM-IV mania or hypomania with elated mood and/or grandiosity as one criterion; g. The rates of irritability, elated mood, and grandiosity were not significantly different between pre-pubertal and pubertal BD subjects; h. Irritable mood: BD $v s$. ADHD $\chi^{2}=13.6$, $\mathrm{p}<0.001$; BD vs. HC $\chi^{2}=45.7, \mathrm{p}<0.0001$; g. Elated mood: BD vs. ADHD $\chi^{2}=64.2, \mathrm{p}<0.0001$; . Grandiosity: BD $v s$. ADHD $\chi^{2}=61.0$, p $<0.0001$; BD $v s$. HC $\chi^{2}=36.6$, $\mathrm{p}<0.0001$; h. Prevalently Elated group: distinctly elated mood, euphoria, and inflated self-esteem/grandiosity, with or without concomitant irritable mood, Prevalently irritable group: irritability and dysphoria but no prominent elated mood.; i. Episodic course: episodes lasting at least 7 days, more frequently superimposed on a less severely impaired baseline, fulfilling the adult diagnostic criteria for rapid cycling $B D(>4$ episodes/year). In subjects with chronic course, the duration of the illness was at least 6 months, but usually the subjects remained clearly symptomatic for 1 or 2 years. The Episodic course was more frequent in patients with elated mood, while Chronic course was more frequent in patients with irritable mood; l. BD subjects with comorbid ADHD had a prevalent chronic course and irritable mood, had a greater clinical severity and functional impairment, had a manic/ mixed index episode, had a higher risk of conduct disorder, and were more resistant to treatments, according to the CGI-Improvement scores $(\mathrm{P}<.0001)$; m. Mania was defined by DSM-IV criteria, with at least one of the two cardinal symptoms of mania elated mood and/or grandiosity. Table 1 shows the prevalence of symptoms reported by parent only or child only or both informants; n. No difference were found between Irritable only vs. Irritable+Elated subjects in the rate of mania symptoms with the exception of "increased activity at school" which was higher in the children that had both irritability and euphoria. 
disturbances and hyperactivity. Course pattern is mostly rapid or ultra-rapid with frequent mood shifts during a same day, whereas the classical episodic course is less common during juvenile years [1, 7-10].

Pediatric onset of $\mathrm{BD}$ is associated with elevated risks for substance abuse and addiction, anxiety, conduct and antisocial disorders, with high levels of morbidity and disability, as well as an increased risk of suicide [11-13]. Reported latency between initial affective symptoms and a first major affective episode in BD is 8-12 years, with up to another 9 years from a first affective episode to initiation of appropriate mood-stabilizing treatment [14-16].

More research is needed to identify early manifestation of pediatric mania in the youngest individuals, improve its differential diagnosis with other juvenile disorders such as ADHD and delineate the potential predictors of diagnostic stability and continuity between pediatric and adult bipolar disorder.

\section{Clinical Picture of Pediatric Mania}

According to the Diagnostic and Statistical Manual for Mental Disorders (DSM V) [17], mania can be characterized by a severe and impairing abnormal mood state that is either euphoric or irritable. These two sides of mania have been observed and well described in clinical descriptions of bipolar children and adolescents. Euphoria is characterized by an elated, high-energy state with grandiose feelings and ideas. Children in this state appear cheerful, over-the-top funny, sometimes hilarious, and frequently show immaturegiddy behaviors that are difficult to be contained by both parents and peers. These children may also be grandiose with over-confidence, taking on unrealistic projects and defying adult authority to an extreme degree [18].

The other mood state of mania is characterized by irritability. In adult patients, clinicians frequently diagnose impairing mixed states (or dark mania) with extreme irritability. In children or adults, these mood states can appear as nastiness, blaming, demanding, whining, or viciousness, characterized by explosive rages that can be physically abusive, destructive and dangerous [18]. Irritability, though highly debated as characteristic of many disorders, is as an important manic feature. When occurring frequently and intensely, the quality and quantity of irritability can distinguish a bipolar diagnosis. Even in the presence of other classic symptoms of melancholy and euphoria, irritability is often the most impairing aspect of the clinical picture and often forms the chief complaint for referral to psychiatric services. Irritability without euphoria has been reported as the most common mood presentation in children presenting with PBD [7], with high levels of impairment and morbidity and is often associated with impulsive and reckless behaviors, violent gestures and impulsive suicidal thoughts, threats and behaviors [7, 19-21].

Mixed states with high levels of irritability have been commonly reported in adults with bipolar disorder. For these patients, psychosis, aggressive behaviors and psychomotor agitation can be a primary cause of hospitalization [6].
We reviewed the available studies on the phenomenology of pediatric mania with the aim of summarizing the prevalence, demographics, clinical correlates and course of these two types of pediatric mania.

\section{METHODS}

A Pubmed literature search using key terms including pediatric mania/bipolar disorder, childhood onset mania/ bipolar disorder, juvenile onset bipolar disorder was conducted. From the identified articles, additional articles were noted in the reference sections. Of the articles, eighteen were identified which reported the number of subjects with either irritability or elation as the presenting mood symptom in samples of subjects younger than age 18 years old.

\section{RESULTS}

Eighteen studies reporting the number of subjects presenting with either irritable or elated mood during mania or informing about the rating of manic symptoms were identified and summarized in Table 1. Information reported in the Table include the study design, the type of sample with age range and mean, the prevalence of irritability, elation and grandiosity symptoms in each sample as available and information on the course pattern of the disorder (Table 1). While all studies report high rates of both euphoria and irritability, 14 of the 18 studies report irritability as a predominant mood symptom. For studies which reported euphoria, irritability and the combined state, the combined state of 'euphoria+irritability' is the most common mood presentation, but these studies varied in their methodology of establishing the mood state, with some asking for a week or longer of the mood state to code it while others ask for a week or longer of either mood state and code the combined condition if both abnormal moods are present at all. Eight studies provide information on cycling patterns, with rapid cycling or chronic course most commonly reported.

\section{DISCUSSION}

\section{Clinical Symptoms: Irritability Versus Elation}

Our report summarizing the predominant mood presentation in youth with mania supports the importance of irritability in diagnosing pediatric bipolar disorder. Some investigators $[10,22,23]$ have argued that euphoria (as opposed to irritability) is unique to bipolar disorder and therefore should be considered the defining mood disturbance of bipolar children. Other authors (see Table 1) have reported that irritability may be the most common abnormal mood associated with pediatric bipolar disorder [7, $9,10,20,21,24-27]$, with sensitivity reaching $100 \%$ for mania in some samples [28], and therefore should be considered to be a bona fide symptom of mania. Findings from two metaanalysis support this latter view and found high rates of irritability in all age groups with mania suggesting that irritability may be a marker of mania in children and that euphoria and grandiosity are usually less common in children than in adults $[1,29]$. 
The prevalence of irritable mood varies in relation to the inclusion criteria of the analyzed sample. In fact in some reports bipolar subjects had been included only if presenting with one of the two cardinal symptoms elation or grandiosity. In these samples the prevalence of irritability as associated mood symptom can be low (29\% in the bipolar sample with anxious comorbid disorder reported by Masi and colleagues [30]) but usually is reported to be present in more than $90 \%$ of the cases in association with euphoria [9]. Some samples required 'a week or longer' of the mood state to be coded as present while others required a week or longer of abnormal mood and coded elation or irritability if present at all during this week. Some studies reported a severity rating for these symptoms.

Some authors reported that pediatric subjects with irritable mania are significantly younger than those presenting euphoric mania [30, 31] and that the irritability score significantly decreased linearly with age [32]. Accordingly, retrospective studies found that irritability, mood lability and impulse dyscontrol may be the predominant psychopathological features of pediatric bipolar disorder at onset $[33,34]$. A possible explanation of this finding might be that irritability is generally a highly prevalent psychopathological feature during pediatric age.

Moreover, several independent laboratories have shown that bipolar youth with predominantly irritable mood do not significantly differ from those presenting with euphoric mood in their profile of symptoms of mania, measures of social functioning and long-term outcome [20, 35]. Some authors suggest that patterns of comorbidity may be different with prevalently irritable subjects, who have higher rates of comorbidity with ADHD and other externalizing disorders and a chronic course, whereas euphoric manic subjects more frequently show an episodic course and a comorbid anxiety disorder [30].

\section{Course Pattern: Episodic Versus Rapid and Ultra-rapid Cycling}

Despite debate regarding chronicity and episodicity in pediatric mania, only half the studies reviewed reported on number of episodes or cycling patterns. The duration of manic episodes can range from brief tantrum-like affective storms lasting minutes or hours to longer episodes persisting for several days or months. The existence of very short episodes of mania lasting minutes or hours and the consequent identification of a ultra-ultra-rapid course pattern of pediatric bipolar disorder characterized by more than 365 cycles per year (at least one mood shift per day) or ultrarapid course pattern (with 5-365 cycles per year) is another highly debated point among authors analyzing pediatric mood disorder phenomenology [24].

Current DSM-V criteria (and also the previous DSM-IV criteria) for mania include the duration criteria of at least 47 consecutive days of abnormal mood state respectively for hypomania and mania [17]. For this reason, many juvenile bipolar subjects are currently classified as Bipolar Not Otherwise Specified (NOS) for which several research groups have operationalized symptom criteria aimed at classifying brief and severe manic and hypomanic episodes [36].

Explosive temper outbursts that are considered by many authors as a common manifestation of short episodes of irritable mania, have been included in DSM-V as the new syndrome Disruptive Mood Dysregulation Disorder (DMDD) that is classified among unipolar depressive mood disorders with the aim of differentiating subjects presenting with chronic versus episodic irritability.

This new category stands in contrast to the very high rate of ultra-ultra-rapid and ultra-rapid cycling bipolar course characterized by ultradian mood cycling described by several authors as the most common presentation of bipolar disorder during pre-pubertal and early adolescent age [7, 9, 24]. In fact, $65-80 \%$ of juvenile bipolar subjects were reported to present an ultra-ultra-rapid course pattern, followed by the ultra-rapid and rapid course, whereas the classical episodic presentation of depressive and manic episodes is more rare in juvenile ages [7, 24, 25]. Moreover several longitudinal course studies showed that bipolar patients spend most of the time suffering from a sub-syndromal mixed and depressive symptomatology, miming the chronic mood dysregulation $[35,37,38]$.

Masi and colleagues reported that even patients with an episodic pattern showed a rapid cycling course ( $>4$ episodes per year) and that a chronic course was identified in $43 \%$ of a bipolar juvenile sample [30]. Patients with a chronic course were reported to be younger, mostly irritable when manic, with an earlier onset of $\mathrm{BD}$ and with more comorbid externalizing disorders when compared to juvenile subjects with an episodic bipolar disorder [39].

\section{Long-term Outcome: Mania Versus SMD/DMDD}

Findings from retrospective studies of adult bipolar disorder patients indicate that between one-third to more than half had experienced early psychopathological symptoms during childhood or adolescence [16, 34, 40]. Perlis et al. reported that $65 \%$ of a large $(\mathrm{N}=983)$ sample of bipolar adults reported mood symptoms starting in the prepubertal $(28 \%)$ or adolescent years (37\%) [41]. These reports suggest that pediatric mania can and does persist into the adult years.

Typical reported early features include mood swings, early depressive symptoms, dysregulated mood, activity and sleep patterns, irritability and disordered behaviors including aggression [33, 42]. Longitudinal, including high risk family studies, are consistent with retrospective studies in identifying that sub-syndromal depressive and hypomanic symptoms often precede bipolar disorder by several years $[33,43]$ with a reported latency between initial affective symptoms and the first identified major affective episode in $\mathrm{BD}$ between 8 to 12 years [34], with another 8 to 10 years from the first affective episode to the initiation of an appropriate mood-stabilizing treatment [14-16]. An important clinical and prognostic aspect of undiagnosed and untreated early BD is an elevated risk of substance misuse, anxiety disorders as well as conduct and antisocial disorders, with high levels of morbidity, disability and suicide [12, 44]. 
Also, adult mood disorders with a juvenile onset are more severe and more recurrent than similar illnesses starting in adult years [12, 15, 41]. Particularly, childhood onset BD was associated with a greater number of episodes, higher percent time ill, a higher risk of rapid cycling and more severe manic and depressive episodes [12, 41], as well as with greater rates of other psychiatric disorders, especially with comorbid anxiety disorders and substance abuse, with greater likelihood of suicide attempts and violent behaviors [41].

The fact that untreated and early onset bipolar disorder results in a worse clinical outcome highlights the importance of a closer linkage between pediatric and adult psychiatry, to clarify the natural history of childhood disorders by their outcomes and in order to predict the diagnosis, course and prognosis of adult mood disorders, with the possible aim of improving long term adult outcomes.

Some authors have reported findings strongly supporting continuity between pediatric and adult bipolar disorders. Geller and colleagues followed for 8 years 115 PBD-I subjects presenting on average at age 11 years with a manic or mixed episode [37]. At the end of the 8 year follow-up period, results showed that subjects spent $60.2 \%$ of the weeks in any mood episode and $40 \%$ of the weeks in manic episodes. Also, at the end of follow-up 54/115 subjects were 18 years or older and continue to have manic episodes in $44 \%$ of cases while $35 \%$ also had a comorbid substance abuse disorder, a rate that is similar to that found in adult BD-I subjects [37].

Wozniak and colleagues documented a highly persistent course of bipolar disorder in youth. These authors followedup after 4 years 78 PBD-I subjects who were an average age of 13.4 years at intake. At the end of follow-up period, $73 \%$ of subjects continued to meet full diagnostic criteria for BDI, 6.4\% met criteria for sub-syndromal mania, 5.1\% met criteria for major depressive symptoms (but not mania), 9\% were euthymic but were taking mood-stabilizing medications, and only $6.4 \%$ were euthymic with no medications. This data indicates the importance of considering the full range of persistence in longitudinal samples beyond continued BP-I disorder in order to understand the extent of ongoing morbidity in this population [45].

Hunt and colleagues followed 309 BD subjects presenting a baseline with either irritability only $(n=30)$, elation only $(n=42)$ or irritability and elation $(n=237)$ for 4 years. At the end of follow up most bipolar youth experienced both irritability and elation irrespective of history at baseline and irritable only youth were found to be at similar risk for persistence of mania compared to elated only or irritable and elated subjects. Few studies stratified follow up by the symptoms of irritability and elation or by chronicity versus episodic course, but in this study irritable only subjects experienced a greater depressive morbidity during follow-up than did subjects who were both irritable and elated [35].

With respect to the longitudinal course of the new DSM-V diagnostic category of Disruptive Mood Dysregulation Disorder, a disorder of irritability, some studies have reported that rates of conversion from severe, non-episodic irritability to bipolar disorder are very low [46] and that children with chronic irritability are at risk to develop unipolar depressive and/or anxiety disorders in adulthood $[47,48]$. Brotman and colleagues followed prospectively children meeting criteria for severe mood dysregulation until age 18 and they found that severe mood dysregulated youth were significantly more likely to be diagnosed with a depressive disorder at age 18 when compared to youth with no severe mood dysregulation. Similarly, Copeland and colleagues (2014) reported that young adults with a history of DMDD had elevated rates of anxiety and depression relative to comparison subjects with no history of DMDD and that participants with a history of DMDD were more likely to have adverse health outcome including police contact. The low rates of bipolar disorder in these studies may not be surprising since the exclusionary criteria for DMDD list any symptoms of mania beyond irritability. Axelson and colleagues suggested that DMDD could not be distinguished from oppositional defiant disorder and conduct disorder and was not associated with mood disorders at all [49]. However, since the onset of a major depressive disorder by age 18 has been reported to be a strong predictor of later conversion to bipolar disorder [33, 50] and since, similarly, a unipolar major depressive disorder with associated antisocial behaviors and great functional impairment has been reported to have a high risk to switch to bipolar disorder [42, 51], it seems likely that bipolar disorder would be an outcome of at least some subset of childhood DMDD cases. While the longitudinal course of illness should be taken into account as very important in differentiating complicated clinical pictures in childhood, the results of studies reporting a low long-term outcome rate of bipolar disorder among DMDD subjects should be taken with caution and seen in light of the above discussed limitations.

\section{SUMMARY}

Irritability has been reported to be the most frequent clinical feature of pediatric mania reaching a sensitivity of $95-100 \%$ in several samples (Table 1). Despite this high sensitivity, irritability has been criticized as a nonspecific symptom because it could be a feature of other juvenile psychiatric disorders notably depression and oppositional defiant disorder. Nevertheless, some authors have reported that the quality and quantity of irritability observed in some children may be uniquely associated with mania. This irritability is extremely severe with aggression and outbursts and substantially distinct from the irritability seen in other psychiatric conditions. Taken together, this suggests that irritability as a symptom per se may not be pathognomonic of bipolar disorder, but that the severe form of irritability described in children with bipolar disorder may be considered as an equally meaningful mood criterion for pediatric mania [19] as that of euphoria. Attention to the heterogeneity of irritability could guide future research aimed at differentiating distinct subtypes of pediatric psychiatric disorders with distinct phenomenology, course, outcome and biomarkers. Longitudinal studies of samples attending to mood presentation, irritable versus elated, and course, chronic versus episodic, may help clarify whether these are meaningful distinctions in the course, treatment and outcome of pediatric onset bipolar disorder. 


\section{CONFLICT OF INTEREST}

The authors confirm that this article content has no conflict of interest.

\section{ACKNOWLEDGEMENTS}

Declared none.

\section{REFERENCES}

[1] Faedda, G.L.; Baldessarini, R.J.; Suppes, T.; Tondo, L.; Becker, I.; Lipschitz, D.S. Pediatric-onset bipolar disorder: a neglected clinical and public health problem. Harv. Rev. Psychiatry, 1995, 3(4), 171-195. [http://dx.doi.org/10.3109/10673229509017185] [PMID: 9384947]

[2] Van Meter, A.R.; Moreira, A.L.; Youngstrom, E.A. Meta-analysis of epidemiologic studies of pediatric bipolar disorder. J. Clin. Psychiatry, 2011, 72(9), 1250-1256. [http://dx.doi.org/10.4088/ JCP.10m06290] [PMID: 21672501]

[3] Wozniak, J.; Faraone, S.V.; Martelon, M.; McKillop, H.N.; Biederman, J. Further evidence for robust familiality of pediatric bipolar I disorder: results from a very large controlled family study of pediatric bipolar I disorder and a meta-analysis. J. Clin. Psychiatry, 2012, 73(10), 1328-1334. [http://dx.doi.org/10.4088/ JCP.12m07770] [PMID: 23140652]

[4] Strober, M.; Carlson, G. Bipolar illness in adolescents with major depression: clinical, genetic, and psychopharmacologic predictors in a three- to four-year prospective follow-up investigation. Arch. Gen. Psychiatry, 1982, 39(5), 549-555. [http://dx.doi.org/10.1001/ archpsyc. 1982.04290050029007] [PMID: 7092488]

[5] Geller, B.; Fox, L.W.; Clark, K.A. Rate and predictors of prepubertal bipolarity during follow-up of 6- to 12-year-old depressed children. J. Am. Acad. Child Adolesc. Psychiatry, 1994, 33(4), 461-468. [http://dx.doi.org/10.1097/00004583-19940500000003] [PMID: 8005898]

[6] Goodwin, F.K.; Jamison, K.R. Manic-Depressive Illness: Bipolar Disorders and Recurrent Depression, $2^{\text {nd }}$ ed; Oxford University Press: New York, 2007.

[7] Wozniak, J.; Biederman, J.; Kiely, K.; Ablon, J.S.; Faraone, S.V.; Mundy, E.; Mennin, D. Mania-like symptoms suggestive of childhood-onset bipolar disorder in clinically referred children. $J$. Am. Acad. Child Adolesc. Psychiatry, 1995, 34(7), 867-876. [http:// dx.doi.org/10.1097/00004583-199507000-00010] [PMID: 7649957]

[8] Faedda, G.L.; Baldessarini, R.J.; Glovinsky, I.P.; Austin, N.B. Treatment-emergent mania in pediatric bipolar disorder: a retrospective case review. J. Affect. Disord., 2004, 82(1), 149-158. [http://dx.doi.org/10.1016/j.jad.2003.12.011] [PMID: 15465590]

[9] Geller, B.; Zimerman, B.; Williams, M.; Bolhofner, K.; Craney, J.L.; Delbello, M.P.; Soutullo, C.A. Diagnostic characteristics of 93 cases of a prepubertal and early adolescent bipolar disorder phenotype by gender, puberty and comorbid attention deficit hyperactivity disorder. J. Child Adolesc. Psychopharmacol., 2000, 10(3), 157-164. [http://dx.doi.org/10.1089/10445460050167269] [PMID: 11052405]

[10] Geller, B.; Zimerman, B.; Williams, M.; Delbello, M.P.; Bolhofner, K.; Craney, J.L.; Frazier, J.; Beringer, L.; Nickelsburg, M.J. DSMIV mania symptoms in a prepubertal and early adolescent bipolar disorder phenotype compared to attention-deficit hyperactive and normal controls. J. Child Adolesc. Psychopharmacol., 2002, 12(1), 1125. [http://dx.doi.org/10.1089/10445460252943533] [PMID: 12014591]

[11] Matza, L.S.; Rajagopalan, K.S.; Thompson, C.L.; de Lissovoy, G. Misdiagnosed patients with bipolar disorder: comorbidities, treatment patterns, and direct treatment costs. J. Clin. Psychiatry, 2005, 66(11), 1432-1440. [http://dx.doi.org/10.4088/JCP.v66n1114] [PMID: 16420081]

[12] Leverich, G.S.; Post, R.M.; Keck, P.E., Jr; Altshuler, L.L.; Frye, M.A.; Kupka, R.W.; Nolen, W.A.; Suppes, T.; McElroy, S.L.; Grunze, H.; Denicoff, K.; Moravec, M.K.; Luckenbaugh, D. The poor prognosis of childhood-onset bipolar disorder. J. Pediatr., 2007, 150(5), 485-490. [http://dx.doi.org/10.1016/j.jpeds.2006.10. 070] [PMID: 17452221]

[13] Tondo, L.; Isacsson, G.; Baldessarini, R. Suicidal behaviour in bipolar disorder: risk and prevention. CNS Drugs, 2003, 17(7),
491-511. [http://dx.doi.org/10.2165/00023210-200317070-00003] [PMID: 12751919]

[14] Baldessarini, R.J.; Tondo, L.; Hennen, J.; Floris, G. Latency and episodes before treatment: response to lithium maintenance in bipolar I and II disorders. Bipolar Disord., 1999, 1(2), 91-97. [http://dx.doi.org/10.1034/j.1399-5618.1999.010206.x] [PMID: 11252665]

Post, R.M.; Leverich, G.S.; Kupka, R.W.; Keck, P.E., Jr; McElroy, S.L.; Altshuler, L.L.; Frye, M.A.; Luckenbaugh, D.A.; Rowe, M.; Grunze, H.; Suppes, T.; Nolen, W.A. Early-onset bipolar disorder and treatment delay are risk factors for poor outcome in adulthood. J. Clin. Psychiatry, 2010, 71(7), 864-872. [http://dx.doi.org/10. 4088/JCP.08m04994yel] [PMID: 20667291]

[16] Egeland, J.A.; Hostetter, A.M.; Pauls, D.L.; Sussex, J.N. Prodromal symptoms before onset of manic-depressive disorder suggested by first hospital admission histories. J. Am. Acad. Child Adolesc. Psychiatry, 2000, 39(10), 1245-1252. [http://dx.doi.org/10.1097/ 00004583-200010000-00011] [PMID: 11026178]

[17] American Psychiatric Association. Diagnostic and Statistical Manual of Mental Disorders, Fifth Edition (DSM-5); American Psychiatric Publishing: Arlington, Virginia, 2013.

[18] McDonnell, M.A.; Wozniak, J. Positive Parenting for Bipolar Kids; Bantam Books: New York, 2009.

[19] Mick, E.; Spencer, T.; Wozniak, J.; Biederman, J. Heterogeneity of irritability in attention-deficit/hyperactivity disorder subjects with and without mood disorders. Biol. Psychiatry, 2005, 58(7), 576582. [http://dx.doi.org/10.1016/j.biopsych.2005.05.037] [PMID: 16084859]

[20] Wozniak, J.; Biederman, J.; Kwon, A.; Mick, E.; Faraone, S.; Orlovsky, K.; Schnare, L.; Cargol, C.; van Grondelle, A. How cardinal are cardinal symptoms in pediatric bipolar disorder? An examination of clinical correlates. Biol. Psychiatry, 2005, 58(7), 583-588. [http://dx.doi.org/10.1016/j.biopsych.2005.08.014] [PMID: 16197929]

[21] Wozniak, J.; Biederman, J.; Richards, J.A. Diagnostic and therapeutic dilemmas in the management of pediatric-onset bipolar disorder. J. Clin. Psychiatry, 2001, 62(Suppl. 14), 10-15. [PMID: 11469669]

[22] Geller, B.; Zimerman, B.; Williams, M.; Bolhofner, K.; Craney, J.L. Bipolar disorder at prospective follow-up of adults who had prepubertal major depressive disorder. Am. J. Psychiatry, 2001, 158(1), 125-127. [http://dx.doi.org/10.1176/appi.ajp.158.1.125] [PMID: 11136645]

[23] Leibenluft, E.; Charney, D.S.; Towbin, K.E.; Bhangoo, R.K.; Pine, D.S. Defining clinical phenotypes of juvenile mania. Am. $J$ Psychiatry, 2003, 160(3), 430-437. [http://dx.doi.org/10.1176/appi. ajp.160.3.430] [PMID: 12611821]

[24] Faedda, G.L.; Baldessarini, R.J.; Glovinsky, I.P.; Austin, N.B. Pediatric bipolar disorder: phenomenology and course of illness. Bipolar Disord., 2004, 6(4), 305-313. [http://dx.doi.org/10.1111/ j.1399-5618.2004.00128.x] [PMID: 15225148]

[25] Biederman, J.; Faraone, S.V.; Wozniak, J.; Mick, E.; Kwon, A.; Aleardi, M. Further evidence of unique developmental phenotypic correlates of pediatric bipolar disorder: findings from a large sample of clinically referred preadolescent children assessed over the last 7 years. J. Affect. Disord., 2004, 82(Suppl. 1), S45-S58. [http://dx.doi.org/10.1016/j.jad.2004.05.021] [PMID: 15571789]

[26] Luby, J.; Belden, A. Defining and validating bipolar disorder in the preschool period. Dev. Psychopathol., 2006, 18(4), 971-988. [http://dx.doi.org/10.1017/S0954579406060482] [PMID: 17064425]

[27] Tillman, R.; Geller, B.; Craney, J.L.; Bolhofner, K.; Williams, M.; Zimerman, B. Relationship of parent and child informants to prevalence of mania symptoms in children with a prepubertal and early adolescent bipolar disorder phenotype. Am. J. Psychiatry, 2004, 161(7), 1278-1284. [http://dx.doi.org/10.1176/appi.ajp.161. 7.1278] [PMID: 15229062]

[28] Scheffer, R.E.; Niskala A.J.A. The diagnosis of preschool bipolar disorder presenting with mania: open pharmacological treatment. $J$. Affect. Disord., 2004, 82(Suppl. 1), S25-S34. [http://dx.doi.org/10. 1016/j.jad.2004.05.019] [PMID: 15571787]

[29] Kowatch, R.A.; Youngstrom, E.A.; Danielyan, A.; Findling, R.L. Review and meta-analysis of the phenomenology and clinical characteristics of mania in children and adolescents. Bipolar Disord., 2005, 7(6), 483-496. [http://dx.doi.org/10.1111/j.13995618.2005.00261.x] [PMID: 16403174] 
[30] Masi, G.; Perugi, G.; Toni, C.; Millepiedi, S.; Mucci, M.; Bertini, N.; Akiskal, H.S. The clinical phenotypes of juvenile bipolar disorder: toward a validation of the episodic-chronic-distinction. Biol. Psychiatry, 2006, 59(7), 603-610. [http://dx.doi.org/10.1016/j. biopsych.2005.08.034] [PMID: 16487492]

[31] Hunt, J.; Birmaher, B.; Leonard, H.; Strober, M.; Axelson, D.; Ryan, N.; Yang, M.; Gill, M.; Dyl, J.; Esposito-Smythers, C.; Swenson, L.; Goldstein, B.; Goldstein, T.; Stout, R.; Keller, M. Irritability without elation in a large bipolar youth sample: frequency and clinical description. J. Am. Acad. Child Adolesc. Psychiatry, 2009, 48(7), 730-739. [http://dx.doi.org/10.1097/ CHI.0b013e3181a565db] [PMID: 19465878]

[32] Demeter, C.A.; Youngstrom, E.A.; Carlson, G.A.; Frazier, T.W.; Rowles, B.M.; Lingler, J.; McNamara, N.K.; Difrancesco, K.E.; Calabrese, J.R.; Findling, R.L. Age differences in the phenomenology of pediatric bipolar disorder. J. Affect. Disord., 2013, 147(1-3), 295-303. [http://dx.doi.org/10.1016/j.jad.2012.11.021] [PMID: 23219057]

[33] Faedda, G.L.; Marangoni, C.; Serra, G.; Salvatore, P.; Sani, G.; Vázquez, G.H.; Tondo, L.; Girardi, P.; Baldessarini, R.J.; Koukopoulos, A. Precursors of bipolar disorders: a systematic literature review of prospective studies. J. Clin. Psychiatry, 2015, 76(5), 614-624. [http://dx.doi.org/10.4088/JCP.13r08900] [PMID: 26035191]

[34] Serra, G.; Koukopoulos, A.; De Chiara, L.; Napoletano, F.; Koukopoulos, A.E.; Curto, M.; Manfredi, G.; Faedda, G.; Girardi, P.; Baldessarini, R.J. Features preceding diagnosis of bipolar versus major depressive disorders. J. Affect. Disord., 2015, 173, 134-142. [http://dx.doi.org/10.1016/j.jad.2014.10.050] [PMID: 25462407]

[35] Hunt, J.I.; Case, B.G.; Birmaher, B.; Stout, R.L.; Dickstein, D.P.; Yen, S.; Goldstein, T.R.; Goldstein, B.I.; Axelson, D.A.; Hower, H.; Strober, M.; Ryan, N.; Swenson, L.; Topor, D.R.; Gill, M.K.; Weinstock, L.M.; Keller, M.B. Irritability and elation in a large bipolar youth sample: relative symptom severity and clinical outcomes over 4 years. J. Clin. Psychiatry, 2013, 74(1), e110-e117. [http://dx.doi.org/10.4088/JCP.12m07874] [PMID: 23419232]

[36] Axelson, D.; Birmaher, B.; Strober, M.; Gill, M.K.; Valeri, S.; Chiappetta, L.; Ryan, N.; Leonard, H.; Hunt, J.; Iyengar, S.; Bridge, J.; Keller, M. Phenomenology of children and adolescents with bipolar spectrum disorders. Arch. Gen. Psychiatry, 2006, 63(10), 1139-1148. [http://dx.doi.org/10.1001/archpsyc.63.10.1139] [PMID: 17015816]

[37] Geller, B.; Tillman, R.; Bolhofner, K.; Zimerman, B. Child bipolar I disorder: prospective continuity with adult bipolar I disorder; characteristics of second and third episodes; predictors of 8-year outcome. Arch. Gen. Psychiatry, 2008, 65(10), 1125-1133. [http:// dx.doi.org/10.1001/archpsyc.65.10.1125] [PMID: 18838629]

[38] Birmaher, B.; Axelson, D.; Strober, M.; Gill, M.K.; Yang, M.; Ryan, N.; Goldstein, B.; Hunt, J.; Esposito-Smythers, C.; Iyengar, S.; Goldstein, T.; Chiapetta, L.; Keller, M.; Leonard, H. Comparison of manic and depressive symptoms between children and adolescents with bipolar spectrum disorders. Bipolar Disord., 2009, 11(1), 52-62. [http://dx.doi.org/10.1111/j.1399-5618.2008. 00659.x] [PMID: 19133966]

[39] Masi, G.; Mucci, M.; Pfanner, C.; Berloffa, S.; Magazù, A.; Perugi, G. Developmental pathways for different subtypes of early-onset bipolarity in youths. J. Clin. Psychiatry, 2012, 73(10), 1335-1341. [http://dx.doi.org/10.4088/JCP.11 m07504] [PMID: 23058936]

[40] Lish, J.D.; Dime-Meenan, S.; Whybrow, P.C.; Price, R.A.; Hirschfeld, R.M. The National Depressive and Manic-depressive Association (DMDA) survey of bipolar members. J. Affect. Disord., 1994, 31(4), 281-294. [http://dx.doi.org/10.1016/01650327(94)90104-X] [PMID: 7989643]

[41] Perlis, R.H.; Miyahara, S.; Marangell, L.B.; Wisniewski, S.R.; Ostacher, M.; DelBello, M.P.; Bowden, C.L.; Sachs, G.S.; Nierenberg, A.A. Long-term implications of early onset in bipolar disorder: data from the first 1000 participants in the systematic treatment enhancement program for bipolar disorder (STEP-BD).
Biol. Psychiatry, 2004, 55(9), 875-881. [http://dx.doi.org/10.1016/ j.biopsych.2004.01.022] [PMID: 15110730]

[42] Faedda, G.L.; Serra, G.; Marangoni, C.; Salvatore, P.; Sani, G.; Vázquez, G.H.; Tondo, L.; Girardi, P.; Baldessarini, R.J.; Koukopoulos, A. Clinical risk factors for bipolar disorders: a systematic review of prospective studies. J. Affect. Disord., 2014, 168, 314-321. [http://dx.doi.org/10.1016/j.jad.2014.07.013] [PMID: 25086290]

[43] Duffy, A. The early natural history of bipolar disorder: what we have learned from longitudinal high-risk research. Can. J. Psychiatry, 2010, 55(8), 477-485. [PMID: 20723275]

[44] Perlis, R.H.; Dennehy, E.B.; Miklowitz, D.J.; Delbello, M.P.; Ostacher, M.; Calabrese, J.R.; Ametrano, R.M.; Wisniewski, S.R.; Bowden, C.L.; Thase, M.E.; Nierenberg, A.A.; Sachs, G. Retrospective age at onset of bipolar disorder and outcome during two-year follow-up: results from the STEP-BD study. Bipolar Disord., 2009, 11(4), 391-400. [http://dx.doi.org/10.1111/j.13995618.2009.00686.x] [PMID: 19500092]

[45] Wozniak, J.; Petty, C.R.; Schreck, M.; Moses, A.; Faraone, S.V.; Biederman, J. High level of persistence of pediatric bipolar-I disorder from childhood onto adolescent years: a four year prospective longitudinal follow-up study. J. Psychiatr. Res., 2011, 45(10), 1273-1282. [http://dx.doi.org/10.1016/j.jpsychires.2010. 10.006] [PMID: 21683960]

[46] Stringaris, A.; Baroni, A.; Haimm, C.; Brotman, M.; Lowe, C.H.; Myers, F.; Rustgi, E.; Wheeler, W.; Kayser, R.; Towbin, K.; Leibenluft, E. Pediatric bipolar disorder versus severe mood dysregulation: risk for manic episodes on follow-up. J. Am. Acad. Child Adolesc. Psychiatry, 2010, 49(4), 397-405. [PMID: 20410732]

[47] Brotman, M.A.; Schmajuk, M.; Rich, B.A.; Dickstein, D.P.; Guyer, A.E.; Costello, E.J.; Egger, H.L.; Angold, A.; Pine, D.S.; Leibenluft, E. Prevalence, clinical correlates, and longitudinal course of severe mood dysregulation in children. Biol. Psychiatry, 2006, 60(9), 991-997. [http://dx.doi.org/10.1016/j.biopsych.2006. 08.042] [PMID: 17056393]

[48] Copeland, W.E.; Shanahan, L.; Egger, H.; Angold, A.; Costello, E.J. Adult diagnostic and functional outcomes of DSM-5 disruptive mood dysregulation disorder. Am. J. Psychiatry, 2014, 171(6), 668674. [http://dx.doi.org/10.1176/appi.ajp.2014.13091213] [PMID: 24781389]

[49] Axelson, D.; Findling, R.L.; Fristad, M.A.; Kowatch, R.A.; Youngstrom, E.A.; Horwitz, S.M.; Arnold, L.E.; Frazier, T.W.; Ryan, N.; Demeter, C.; Gill, M.K.; Hauser-Harrington, J.C.; Depew, J.; Kennedy, S.M.; Gron, B.A.; Rowles, B.M.; Birmaher, B. Examining the proposed disruptive mood dysregulation disorder diagnosis in children in the Longitudinal Assessment of Manic Symptoms study. J. Clin. Psychiatry, 2012, 73(10), 1342-1350. [http://dx.doi.org/10.4088/JCP.12m07674] [PMID: 23140653]

[50] Baldessarini, R.J.; Faedda, G.L.; Offidani, E.; Vázquez, G.H.; Marangoni, C.; Serra, G.; Tondo, L. Antidepressant-associated mood-switching and transition from unipolar major depression to bipolar disorder: a review. J. Affect. Disord., 2013, 148(1), 129-135. [http://dx.doi.org/10.1016/j.jad.2012.10.033] [PMID: 23219059]

[51] Morcillo, C.; Duarte, C.S.; Sala, R.; Wang, S.; Lejuez, C.W.; Kerridge, B.T.; Blanco, C. Conduct disorder and adult psychiatric diagnoses: associations and gender differences in the U.S. adult population. J. Psychiatr. Res., 2012, 46(3), 323-330. [http://dx.doi. org/10.1016/j.jpsychires.2011.10.012] [PMID: 22172996]

[52] Rucklidge, J.J. Retrospective parent report of psychiatric histories: do checklists reveal specific prodromal indicators for postpubertalonset pediatric bipolar disorder? Bipolar Disord., 2008, 10(1), 5666. [http://dx.doi.org/10.1111/j.1399-5618.2008.00533.x] [PMID: 18199242]

[53] Staton, D.; Volness, L.J.; Beatty, W.W. Diagnosis and classification of pediatric bipolar disorder. J. Affect. Disord., 2008, 105(1-3), 205-212. [http://dx.doi.org/10.1016/j.jad.2007.05.015] [PMID: 17604120] 